\author{
Нікішина О.В. \\ кандидат економічних наук, старший науковий співробітник \\ відділ ринкових механізмів та структур \\ Інститут проблем ринку та економіко-екологічних досліджень НАН України \\ Французький бульвар, 29, м. Одеса, Україна, 65044 \\ E-mail: ksenkych@gmail.com
}

\title{
КОНЦЕПТУАЛЬНИЙ ПІДХІД ДО СЕЛЕКТИВНОГО РЕГУЛЮВАННЯ ВІДТВОРЮВАЛЬНИХ ПРОЦЕСІВ У СИСТЕМІ СУМІЖНИХ РИНКІВ ЗЕРНА ТА ПРОДУКТІВ ЙОГО ПЕРЕРОБКИ
}

\begin{abstract}
Визначено змістовну сутність категорії «стійкий відтворювальний розвиток». Обґрунтовано концептуальний підхід до селективного регулювання відтворювальних процесів у системі вертикально суміжних ринків зерна та продуктів його переробки, що органічно поєднав два напрями. Перший передбачає нівелювання деформацій процесів відтворення шляхом впровадження інтервенційних, організаційних і інституційних механізмів регулювання. Другий напрям орієнтований на стимулювання продукування доданої вартості товарів у ресурсоутворювальних секторах ринку, що позиціонуються як «точки зростання», шляхом реалізації відтворювальних регуляторних механізмів.

Ключові слова: ринки зерна та продуктів його переробки, система суміжних ринків, дефрормації відтворювальних процесів, ресурсоутворювальні сектори, оптимізація товарних потоків, селективне регулювання.
\end{abstract}

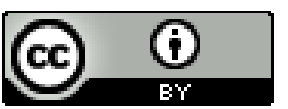

This work is licensed under a Creative Commons Attribution 4.0 International License http://creativecommons.org/licenses/by/4.0/
Постановка проблеми та її зв'язок з важливими науковими та практичними завданнями. Відповідно до сучасної теорії розвитку, національна система проходить чотири послідовні етапи (стадії) економічного розвитку [1, с. 445-450]: (1) факторів виробництва; (2) інвестицій; (3) інновацій; (4) багатства. Кожний із перелічених етапів характеризує певний ступінь розвитку продуктивних сил $\mathrm{i}$ виробничих відносин. Перехід від нижчої до вищої стадії відбувається шляхом накопичення і ефективного використання ресурсів у кількісно-якісному вимірі.

Сьогодні Україна знаходиться лише на початковому ресурсному етапі економічного розвитку. Однією з причин нестабільності й вразливості національної економічної системи $є$ втрата нею базової відтворювальної функції. Передумовою переходу до інвестиційної стадії $є$ забезпечення ефективного використання факторів виробництва, передусім їх розширеного відтворення у реальному секторі економіки. Головними структуроутворюючими елементами реального сектору є інтегровані товарні ринки, в межах яких протікає замкнений відтворювальний цикл споживчої вартості товарів, реалізуючи базову відтворювальну функцію ринків. Оскільки наявність і збалансованість відтворювальних процесів (далі ВП) є ознакою стабільності й незалежності системи, рушійною силою і внутрішнім ресурсом сталого економічного зростання держави, саме вони повинні бути об'єктом державного регулювання та ядром новітніх регуляторних концепцій.
Як відомо, економічне зростання входить до складу головних цілей суспільства. У цій якості воно передбачає підвищення матеріального добробуту населення і підтримку національної безпеки. Одночасно економічне зростання $€$ засобом досягнення даних цілей $[1$, с. 450]. Практика свідчить, що розвиток інтегрованих (чотирьохсекторних) товарних ринків, на відміну від скорочених двохсекторних ринків імпортованих товарів, максимально позитивно впливає на економічне зростання держави та соціальну стабілізацію в суспільстві за рахунок створення додаткових робочих місць, нових підприємницьких структур, збільшення бюджетних надходжень, скорочення виробничих циклів та прискорення товарно-грошового обігу. Відповідно, прямий взаємообумовлений зв'язок між рівнем економічного розвитку й станом суспільного відтворювального процесу актуалізують розробки у методологічній площині регулювання саме процесів відтворення, що протікають у секторах інтегрованих товарних ринків та $\epsilon$ внутрішнім ресурсом і джерелом стійкого економічного зростання держави.

Аналіз останніх публікацій по проблемі. Концептуальні основи регулювання агропродовольчих ринків, у т. ч. ринків зерна та продуктів його переробки (далі - ЗПП), знайшли відображення в працях А. Алтухова [2], О. Бородіної [3], С. Кваші [4], В. Лисюка [5], Т. Осташко [6], П. Саблука [7], В. Солопова [8], М. Хорунжого [9] та інших вітчизняних і зарубіжних учених. Питанням формування 
вертикально суміжних ринків присвячені дослідження Р. Баак, Ю. Камеке, Г. Нормана [10], П. Рея та Ж. Тіроля [11]. Водночас недостатньо дослідженим залишається питання формування концептуального базису селективного регулювання систем вертикально суміжних ринків ЗПП, що формує теоретичний фундамент новітньої методології регулювання інтегрованих товарних ринків, орієнтованої на прикладні регуляторні механізми. Ця обставина визначила мету і завдання даної статті.

Формулювання цілей дослідження. Мета статті - обгрунтування концептуального підходу до селективного регулювання ВП у системі суміжних ринків зерна та продуктів його переробки - окреслила низку завдань:

- аналіз понятійно-категоріального апарату досліджуваної проблеми;

- ідентифікація деформацій ВП (відтворювальних розривів) у мезоекономічній системі, які $\epsilon$ об'єктом селективного регулювання;

- визначення ресурсоутворювальних секторів («точок зростання») у системі суміжних ринків, обгрунтування моделей оптимізації товаропотоків;

- побудова структурно-логічної схеми методологічного підходу до селективного регулювання ВП у системі вертикально суміжних ринків ЗПП.

Виклад основних результатів та їх обгрунтування. Ресурсним фундаментом економічного розвитку країни $є$ стійкий відтворювальний розвиток основних ресурсоутворюючих елементів національного господарства - товарних ринків. Для обгрунтування механізмів регулювання, що забезпечують стійкий розвиток інтегрованих товарних ринків, необхідне глибинне розуміння природи категорій «стійкість» і «розвиток».

Поняття «стійкість» визначає стан динамічної рівноваги економічної системи, тобто іії спроможність зберігати незмінними головні властивості та функції в умовах внутрішніх трансформацій і зовнішніх впливів. Стійкість віддзеркалюе можливості системи захистити внутрішню структуру від внутрішніх несприятливих факторів, а також можливості системи забезпечити взаємодію з зовнішнім середовищем для зміцнення власного стану, тобто існує внутрішня і зовнішня стійкість системи. Параметрами стійкості є безпека, стабільність, надійність, цілісність, міцність, адаптованість системи [12, с. 15].

Стійкість $є$ необхідною умовою якісного розвитку економічної системи. Стійкість пов'язана зі зростанням розмірності та складності, які створюють більші можливості для утворення станів, в яких може відбутися якісна зміна (стрибок) системи. Якщо вона після впливу внутрішніх і зовнішніх чинників повертається у рівноважний стан, але $з$ іншими якостями система розвивається. Зі стійкості випливає розвиток, тому збереження стійкості стає першочерговим завданням для всіх систем. У соціально-економічних системах розвиток представляється як певна стадія розвитку, тобто сукупна зміна у взаємозв'язку кількісних, якісних і структурних категорій $[12$, с. 14-15, 23].
Враховуючи вищевикладене, авторське визначення вихідної дефініції $є$ таким: стійкий відтворювальний розвиток - це процес кількісно-якісних змін у відтворювальному циклі, що охоплює систему суміжних товарних ринків, процес ускладнення іiі структури і розширення складу, в результаті чого підвищується ефективність функціонування системи та їі здатність зберігати рівноважний стан в умовах постійного впливу зовнішніх і внутрішніх чинників. Збереження рівноважного стану передбачає збалансованість внутрішніх і зовнішніх товарно-фінансових потоків у системі суміжних ринків із забезпеченням пріоритетності національних економічних інтересів.

Однією із головних причин втрати стійкості системи суміжних ринків ЗПП є існування низки структурних і фінансових деформацій ВП, які формують відтворювальні «розриви» (міжсекторні й міжринкові) в товарно-фінансових потоках у процесі їх руху за стадіями єдиного відтворювального циклу. Існування таких селективних «розривів» у циклі відтворення споживчої вартості товару обумовлює необхідність обгрунтування та впровадження механізмів селективного державного регулювання, цілеспрямовано зорієнтованих на нівелювання (зменшення) відтворювальних «розривів» у розвитку систем вертикально суміжних товарних ринків.

Термін «селективність» (англ. select - вибирати) трактується як здатність здійснювати відбір, вибірковість; властивість одного об'єкту підбирати властивості іншого об'єкту відповідно до свої потреб i якостей для подальшого сумісного використання i розподілу ресурсів як першого, так і другого об'єкту [13]. Селективність можна розглядати як іманентний атрибут державного регулювання транзитивної економіки. Поява селективності в системі державного регулювання обумовлена «вадами» ринку, тобто його неспроможністю в певних секторах економіки та товарних ринків забезпечити ефективний розподіл ресурсів. Актуальність селективного регулювання підвищується в періоди зміни стадій економічного розвитку, структурних перетворень в макросистемі, економічного спаду, що характеризується обмеженістю державних фінансових ресурсів. Селективність дозволяє усувати з плином часу деформації ВП у вибіркових секторах товарних ринків. У міру нівелювання деформацій та підвищення ефективності функціонування сектору ринку, що є об'єктом регулювання, селективність втрачає для нього значення.

Негативними наслідками державної селективної політики може бути дискримінація розвитку непріоритетних секторів товарного ринку. 3 переходом на нову стадію розвитку у селективної політики 3'являються нові цілі, завдання та важелі, інші сектори товарних ринків стають їі об'єктом. Якісні зміни в структурі економіки вимагають переорієнтації селективної політики. Поступове подолання за допомогою інструментів селективної політики структурних і фінансових деформацій відтворювальних процесів сприяє наближенню транзитивної економіки до розвинутої ринкової системи. 
Селективність обумовлена також пріоритетами державної економічної політики. Проблема реалізації пріоритетів селективного регулювання ускладнюється обмеженістю бюджетних фінансових ресурсів. Держава серед його об'єктів повинна вибирати найбільш значущі та стратегічні, відтворювальний розвиток яких спроможний забезпечити економічну безпеку країни в умовах глобалізаційних викликів. Селективність реалізується в межах цілеспрямованого формування суб'єктами регулювання відносних пропорцій у системах суміжних товарних ринків і системі національної економіки. Під впливом держави відносні пропорції складаються по-іншому, ніж під впливом стихійних ринкових сил або найсильніших суб'єктів господарювання, наділених ринковою владою, оскільки ці пропорції конструюються у площині реалізації економічних інтересів держави та суспільства. Механізм селективного регулювання передбачає впровадження особливого режиму функціонування для окремих груп ринкових суб'єктів, при цьому він може бути як пільговим, так і дискримінаційним. Подібна диференціація властива тільки селективному державному регулюванню.

Головна ідея авторської концепиії селективного державного регулювання відтворювальних про- цесів у системі суміжних ринків ЗПП полягає в тому, що впровадження механізму селективного регулювання, цілеспрямовано зорієнтованого на зменшення (нівелювання) структурних і фінансових деформацій відтворювальних процесів, 3 одного боку, та стимулювання продукування доданої вартості товарів у ресурсоутворювальних (передусім, виробничих) секторах інтегрованих ринків зерна та продуктів його переробки, $з$ іншого, дозволить забезпечити стійкий відтворювальний розвиток системи суміжних ринків.

Дана концепція синтезує в єдину методологічну площину два вектори селективного державного впливу на відтворювальні процеси. Оскільки відтворювальний розвиток включає процеси як спаду, так i зростання, нами запропоновано диференціювати селективне регулювання «відтворювальних розривів» або деформацій відтворювальних процесів (І тип) i «точок зростання» (II тип) у системі вертикально суміжних ринків зерна та продуктів його переробки. Виділені типи селективного державного регулювання розрізняються за об'єктами регулювання, головними завданнями, механізмами регулювання, векторами впливу та очікуваними ефектами, що наочно відображено на рис. 1.

\begin{tabular}{|c|c|}
\hline \multicolumn{2}{|c|}{$\begin{array}{l}\text { Вектори селективного регулювання відтворювальних процесів } \\
\text { у системі суміжних ринків зерна та продуктів його переробки }\end{array}$} \\
\hline $\begin{array}{l}\text { І. Структурні й фінансові деформації відтворю- } \\
\text { вальних процесів }\end{array}$ & $\begin{array}{l}\text { II. Ресурсоутворювальні сектори інтегрованих рин- } \\
\text { ків зерна та продуктів його переробки («точки зрос- } \\
\text { тання») }\end{array}$ \\
\hline $\begin{array}{l}\text { Завдання: забезпечення безперервності відтворю- } \\
\text { вального циклу, збалансованості товарно- } \\
\text { фінансових потоків у системі }\end{array}$ & $\begin{array}{l}\text { Завдання: оптимізація доданої вартості товарів у систе- } \\
\text { мі суміжних ринків, ефективне використання ії ресурс- } \\
\text { ного потенціалу }\end{array}$ \\
\hline $\begin{array}{l}\text { Механізми регулювання: інтервенційні, організа- } \\
\text { ційні та інституційні }\end{array}$ & $\begin{array}{l}\text { Механізми регулювання: відтворювальні, що системно } \\
\text { пов'язують декілька суміжних ринків для досягнення } \\
\text { головного завдання регулювання }\end{array}$ \\
\hline Вплив на систему: стабілізуючий & Вплив на систему: формуючий \\
\hline $\begin{array}{l}\text { Очікувані ефекти: розширене відтворене ресурсів } \\
\text { у секторах інтегрованих ринків ЗПП, узгодження } \\
\text { економічних інтересів суб'єктів різних секторів і } \\
\text { ринків системи }\end{array}$ & $\begin{array}{l}\text { Очікувані ефекти: виробничий (підвищення рівня зава- } \\
\text { нтаження потужностей переробних підприємств), соціа- } \\
\text { льний (створення нових робочих місць), податковий } \\
\text { (зростання податкових надходжень і соціальних виплат) }\end{array}$ \\
\hline
\end{tabular}

Рис. 1. Напрями селективного регулювання відтворювальних процесів у системі суміжних ринків зерна та продуктів його переробки [авторська розробка]

Селективне регулювання I типу передбачає цілеспрямований державний вплив на структурні й фінансові деформації ВП, які генерують відтворювальні «розриви» у єдиному циклі відтворення споживчої вартості товару, порушують збалансований рух товарно-фінансових потоків у межах як інтегрованого зернового ринку, так і системи вертикально суміжних до нього ринків. Враховуючи результати авторських досліджень природи та напрямів структурних і фінансових деформацій ВП $[14,15,16]$, селективні відтворювальні «розриви» у системі вертикально суміж- них до зернового ринків з метою їх подальшого державного регулювання відображено на рис. 2.

На рис. 2 проілюстровано сім типів сучасних структурних деформацій відтворювальних процесів, а саме:

1) зменшення товаропотоків між зерновим i насіннєвим ринками;

2) функціонування похідних переробного та споживчого секторів в межах аграрного сектору зернового ринку;

3) зростання обсягів товаропотоків «тіньового» субсектору ринку продуктів зернопереробки; 


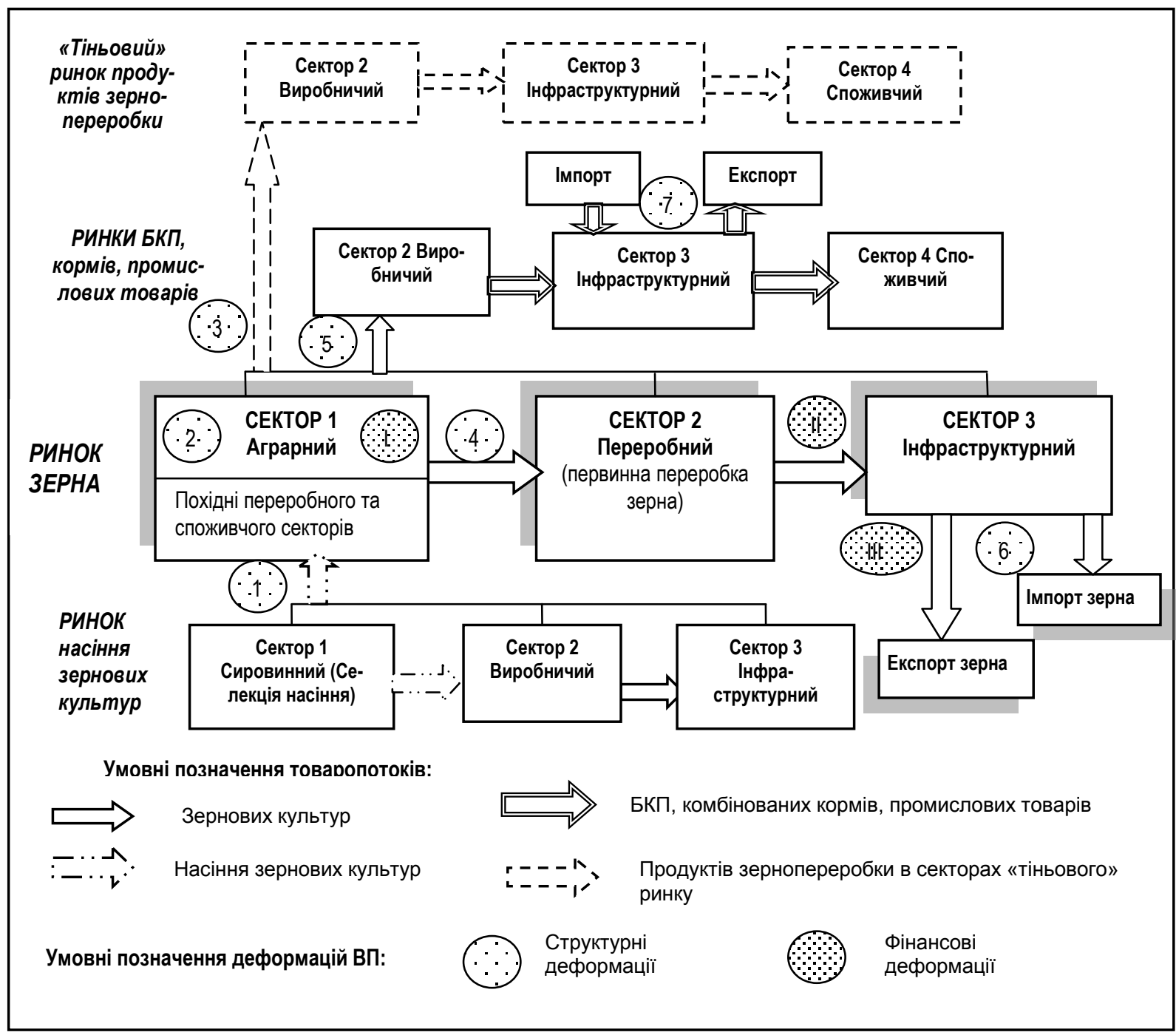

Скорочення: БКП - борошномельно-круп'яна продукція; ВП - відтворювальні процеси.

Рис. 2. Селективні відтворювальні «розриви» у системі вертикально суміжних ринків зерна та продуктів його переробки [авторська розробка]

4) посередні обсяги товаропотоку між аграрним і переробним секторами зернового ринку;

5) зменшення взаємодій між ринками зерна та продуктів його переробки;

6) прискорене зростання сировинного експорту;

7) мізерні обсяги експорту зернопродуктів із високою доданою вартістю.

Фінансові деформації ВП у системі суміжних до зернового ринків ідентифікують «розриви» у русі фінансових потоків та визначають (див. рис. 2):

I. Низький рівень доходності базового аграрного сектора зернового ринку.

II. Непропорційність розподілу доходів між секторами інтегрованого зернового ринку, передусім між аграрним та інфраструктурним.

III. Значні цінові різниці між внутрішніми, експортними, імпортними та світовими цінами зернових культур.

Слід відзначити, що найбільше відтворювальних «розривів» сконцентровано в площині аграрно- го сектору зернового ринку, у вхідних і вихідних товарно-фінансових потоках, які відображають множинність взаємодій зерновиробників із суб'єктами зберігання, зовнішньої реалізації та внутрішньої переробки культур і $є$ проявом неузгодженості економічних інтересів даних суб'єктів, дискримінаційності інтересів аграріїв, передусім малих і середніх форм господарювання (див. рис. 2).

Інструменти (важелі) державного регулювання, цілеспрямовано орієнтовані на нівелювання (зменшення) структурних і фінансових деформацій ВП у системі суміжних до зернового ринків, утворюють специфічні форми селективності. Множинність форм селективності проявляється в регуляторних інструментах. На наш погляд, для нівелювання (зменшення) відтворювальних «розривів» доцільно розробити та впровадити комплекс селективних науковоприкладних заходів, спрямованих на створення розвиненої інфраструктури ринків ЗПП, зростання внутрішнього зернового попиту, поетапну зміну вектору вітчизняного агроекспорту із сировини на зерно- $\mathrm{i}$ 
хлібопродукти тощо. Нівелювання (зменшення) «точок спаду» у системі суміжних до зернового ринків $\epsilon$ необхідною умовою іiі стійкого (рівноважного) відтворювального розвитку. У міру зникнення певних деформацій ВП змінюється форма реалізації селективності, з'являються нові відтворювальні «розриви» та важелі селективного державного регулювання, що здатні результативно впливати на «точки спаду».

Селективне регулювання відтворювальних процесів II типу (див. рис. 1) передбачає стимулювання продукування доданої вартості товарів у ресурсоутворювальних (передусім, виробничих) секторах інтегрованих ринків ЗПП, тобто цільовий вплив на «точки зростання» 3 метою ефективного використання потужних сировинного, інноваційного, виробничого і трудового потенціалів ринків. Ідентифікація цільових «точок зростання» у системі суміжних ринків ЗПП визначає необхідність аналізу багаторівневого алгоритму формування показника загальної дода - ної вартості (ДВ $\boldsymbol{B}_{3 A \Gamma}$ ), що є внутрішнім ресурсом стійкого відтворювального розвитку мікро-, мезо- і макросистем.

Загальна додана вартість товарів у системі вертикально суміжних до зернового ринків (рис. 3) формується як сума доданих вартостей, створених у секторах нижньосуміжного ринку насіння $\left(\boldsymbol{Д}_{\boldsymbol{H}}\right)$, релевантного ринку зерна (ДВ $\left.\boldsymbol{B}_{3}\right)$, верхньосуміжних ринків борошномельно-круп'яної (ДВ

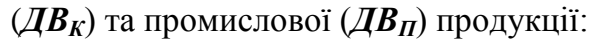

$$
Д B_{3 A \Gamma}=Д B_{H}+Д B_{3}+Д B_{Б}+Д B_{K}+Д B_{I I} \text { (1) }
$$

Кількість доданків у формулі (1) визначається кількістю товарних ринків, включених до системи, та залежить від ступеня переробки зернових культур. У високорозвиненій системі суміжних ринків, яка передбачає глибинну переробку зерна, кількість суміжних ринків може досягати до 40 (саме стільки можна отримати продуктів зернопереробки з високою доданою вартістю).

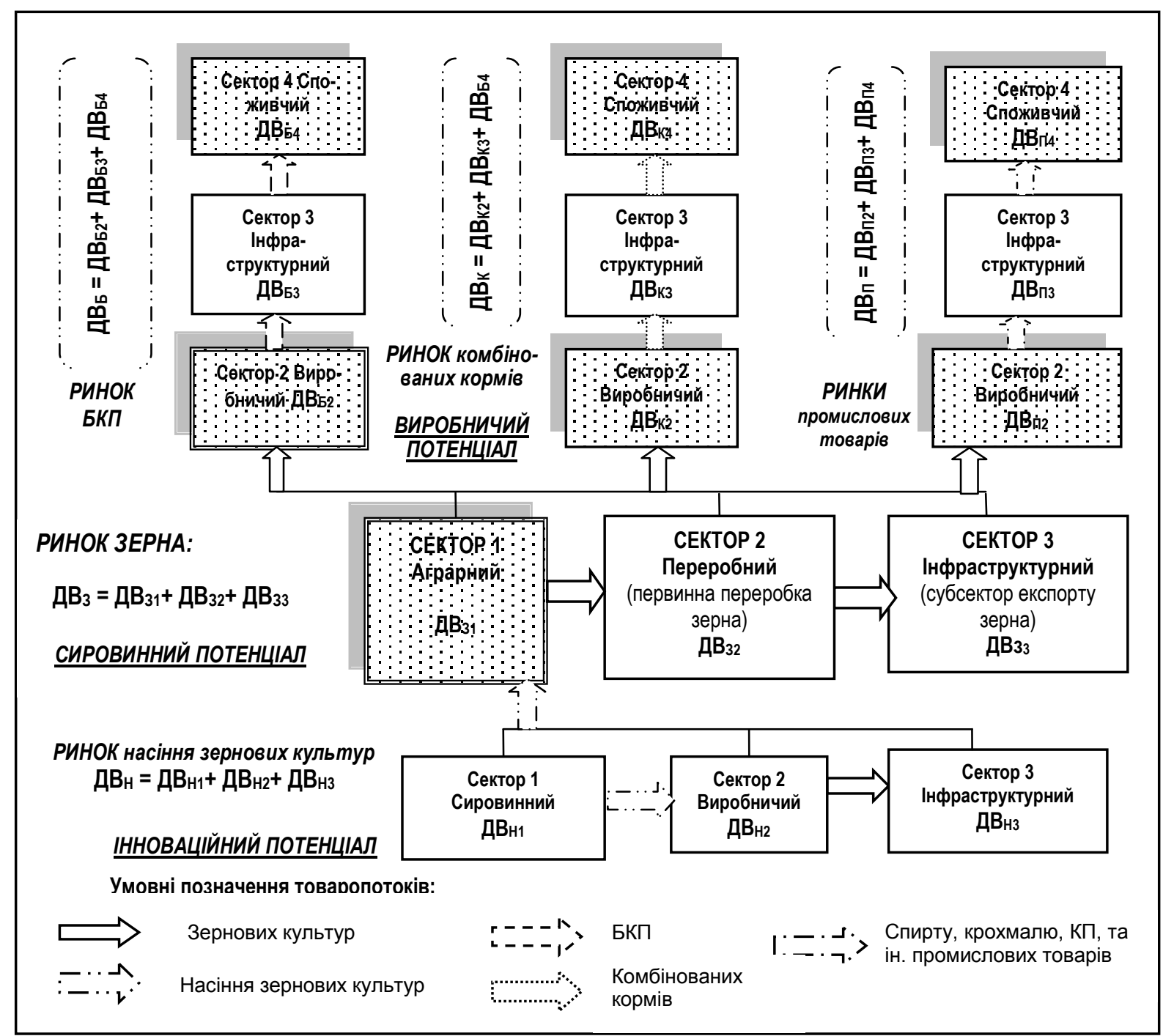

Скорочення: БКП - борошномельно-круп'яна продукція; ДВ - додана вартість товарів у секторах ринків насіння (ДВ товарів (ДВ П)

Рис. 3. Ресурсоутворювальні сектори («точки зростання») у системі вертикально суміжних ринків зерна та продуктів його переробки [авторська розробка] 
У свою чергу, кожен з п'яти складових доданої вартості (у розрізі ринків) включає три секторні показники, які визначають внутрішній внесок кожного сектору в формування доданої вартості певного інтегрованого ринку. При цьому мають місце такі рівності:

$$
\begin{aligned}
& Д B_{H}=Д B_{H 1}+Д B_{H 2}+Д B_{H 3} \\
& Д B_{3}=Д B_{31}+Д B_{32}+Д B_{33} \\
& Д B_{6}=Д B_{62}+Д B_{63}+Д B_{54} \\
& Д B_{K}=Д B_{K 2}+Д B_{K 3}+Д B_{K 4} \\
& Д B_{\Pi 1}=Д B_{\Pi 2}+Д B_{\Pi 3}+Д B_{\Pi 4}
\end{aligned}
$$

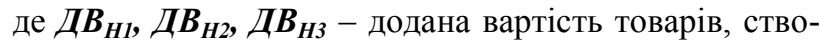
рена в 1, 2, 3 секторах ринку насіння; ДВ $\boldsymbol{B}_{31}, Д_{32}, \boldsymbol{Д}_{33}$ - додана вартість товарів, створена в 1, 2, 3 секторах ринку зернових культур; ДВ вартість товарів, створена в 2, 3, 4 секторах ринку борошномельно-круп'яної продукції; ДВ ДВ $\boldsymbol{B}_{\boldsymbol{K} 4}$ додана вартість товарів, створена в 2, 3, 4 секторах ринку комбікормової продукції; ДВ - додана вартість товарів, створена в 2, 3, 4 секторах ринку продуктів зернопереробки промислового призначення.

Ресурсоутворювальний потенціал різних секторів суміжних ринків неоднаковий як за обсягом, так i структурою. Для визначення найактивніших ресурсогенеруючих секторів («точок зростання») у системі суміжних ринків необхідно побудувати міжсекторні баланси доданої вартості товарів інтегрованих ринків і здійснити їх порівняльний кількісно-структурний аналіз. Важливо враховувати не тільки абсолютне значення показника, але й його секторну структуру (співвідношення заробітної плати, амортизації основних засобів, прибутку та специфічних витрат), обсяги податкових надходжень і соціальних відрахувань, наявність податкових пільг для певних секторів, динаміку змін тощо. При цьому головним орієнтиром для вибору ресурсогенеруюючого сектору $є$ реалізація пріоритету економічних інтересів держави та суспільства.

Ми погоджуємося 3 Д. В. Шияном, який стверджує, що важливою складовою сучасної парадигми аграрної економіки повинно бути широке використання емпіричних даних як критерію перевірки теоретичних положень $[17$, с. 12$]$. За результатами проведених емпіричних досліджень [15, с. 184-185, 199-200] було доведено, що податкове навантаження зростає у міру поглиблення ступеню переробки зерна в технологічних ланцюгах «пшениця - борошно хліб», «кукурудза - комбікорми - продукція тваринництва». Відтак, саме виробничі сектори вносять найбільший вклад (понад 40 \%) у формування загального обсягу податкових надходжень і соціальних відрахувань інтегрованих ринків продуктів зернопереробки, відіграють найвищу податкову роль у системі суміжних ринків. Податковий внесок аграрного сектору є меншим (близько 8-11\%) порівняно з вироб

ничими секторами внаслідок дії низки податкових пільг для сільгоспвиробників, однак він продукує найвищі обсяги доданої вартості товару і є ресурсним фундаментом для формування високорозвиненої системи суміжних ринків.
Таким чином, спираючись на результати аналізу міжсекторних балансів доданої вартості товарів на інтегрованих ринках зернопродуктів, до ресурсогенеруючих секторів у системі суміжних до зернового ринків автором віднесено аграрний сектор, виробничі та споживчі сектори, що проілюстровано на рис. 3. Саме ці сектори є потенційними «точками зростання», об'єктами селективного державного регулювання. Активізація їх відтворювальних функцій обумовлює необхідність зміни вектору та інтенсивності міжринкового руху внутрішніх і зовнішніх товарнофінансових потоків у системах суміжних ринків ЗПП. Так, для зернового ринку така зміна повинна передбачати скорочення обсягів сировинного експорту та зростання обсягів внутрішньої переробки; для ринку борошномельно-круп'яної продукції, враховуючи низький рівень завантаження потужностей, зростання експортних продаж; для ринку комбікормів - збільшення внутрішніх товаропотоків для потреб вітчизняного тваринництва (за умови впровадження результативної державної політики в цій сфері).

Таким чином, забезпечення стійкого відтворювального розвитку систем суміжних ринків ЗПП формує завдання оптимізації інтенсивності внутрішніх i зовнішніх товаропотоків 3 метою активізації «точок зростання». Термін оптимізація (лат. optimus - найкращий) має декілька значень [13]: (1) вибір найкращого варіанту із можливих для досягнення найбільшої ефективності певного процесу 3 урахуванням заданих вимог і обмежень; (2) модифікація системи для підвищення іï ефективності; (3) процес приведення системи в найкращий (оптимальний) стан. Відтак, оптимізація інтенсивності внутрішніх і зовнішніх товаропотоків передбачає трансформацію системи суміжних ринків з метою підвищення ефективності іiі функціонування. Критерієм такої оптимізації є реалізація економічних інтересів держави на досліджуваних ринках, тобто максимізація загальної доданої вартості, що продукується суб'єктами ресурсоутворювальних секторів інтегрованих ринків, i, як наслідок, зростання податкових надходжень і соціальних відрахувань. Таким чином, цільову об'єктну модель селективного державного регулювання можна представити у формалізовану вигляді. Для системи суміжних до зернового (сировинного) ринку вона матиме наступний вигляд:

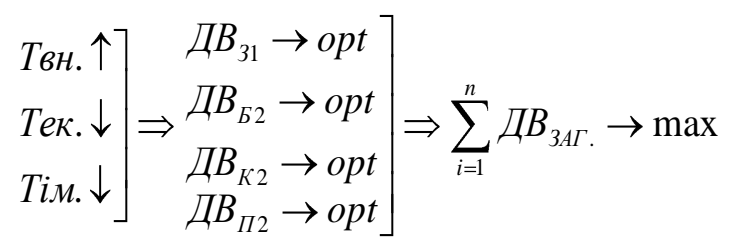

де Твн. - внутрішні товаропотоки; Тек. - експортні товаропотоки; Tiм. - імпортні товаропотоки; $i$ - сектори інтегрованого ринку; $\mathrm{n}$ - кількість секторів у системі суміжних ринків.

Для системи ринків, суміжних до ринків борошномельно-круп'яної й комбікормової продукції (виробничих ринків), формалізована модель така: 


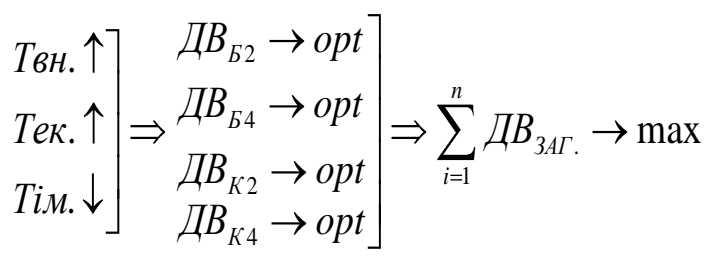

Слід відзначити, що кількість активізованих «точок зростання» залежить від масштабів (глибини) селективного впливу держави. Так, переорієнтація експорту зерна на експорт борошна стимулюватиме зростання доданої вартості у виробничому секторі борошняного ринку (ДВ 2 ), водночас переорієнтація зернового експорту на експорт макаронних виробів сприятиме зростанню доданої вартості у виробничому і споживчому секторах релевантного ринку (ДВ 2 , ДВ $\left.{ }_{54}\right)$, максимізуючи податкові надходження та соціальні відрахування. Враховуючи потужний нереалізований ресурсний потенціал, державі в ході побудови регуляторного механізму доцільно орієнтуватися на мінімальний рівень інтенсивності імпортних товаропотоків у всіх системах суміжних ринків, що знайшло відображення у вигляді їх знижувального вектору в формалізованих моделях (7) і (8).

Дискримінаційність механізму селективного регулювання проявляється в зменшенні обсягів доданої вартості товару (зокрема, прибутку) в інфраструктурному секторі зернового ринку (субсектор експорту), водночас очікувані втрати держави будуть компенсовані приростом новостворюваної вартості у виробничих секторах ринків зернопродуктів (див. рис. 3). Для практичного втілення завдання оптимізації інтенсивності внутрішніх і зовнішніх товаропотоків у системах суміжних ринків ЗПП доцільно обгрунтувати та реалізувати, по-перше, механізми стимулювання експорту вітчизняних продуктів зернопереробки із високою доданою вартістю, по-друге, відтворювальні механізми селективного державного регулювання. Останні передбачають одночасний системний цілеспрямований вплив держави на декілька секторів суміжних ринків для максимізації загальної доданої вартості у системі шляхом нормативноправової регламентації умов певного регуляторного заходу (програми), зобов'язань і кола учасників, векторів їх взаємодій, контролю за дотриманням правил, оцінки бюджетної ефективності заходу тощо.

Прикладом відтворювального механізму селективного державного регулювання є стимулювання виробництва зернових культур (шляхом погектарних дотацій) із заданими параметрами якості для внутрішньої переробки, що передбачає низку законодавчо закріплених умов, як-от: обов'язкове використання аграріями елітного насіння, реалізація вирощеного зерна вітчизняним переробним підприємствам, заборона його експорту, селективність учасників програми, зокрема, надання пріоритету зерновим обслуговуючим кооперативам, фермерським господарствам тощо [15, с. 322-326, 332-336]. Дотримання обмежень, визначених крізь призму економічних інтересів держави, дозволяє підвищити інтенсивність внутрішніх товаропотоків між усіма суміжними ринками системи, активізувати «точки зростання» (див. рис. 3) та забезпечити ефективне використання не тільки сировинно-виробничого, але й інноваційного потенціалу зернового ринку, який сьогодні використовується на третину. Загалом структура та спрямованість відтворювальних механізмів селективного регулювання визначається пріоритетами національної зернової політики, серед яких: задоволення внутрішнього попиту на зернові культури із заданими параметрами якості, зокрема, пшеницю твердих сортів, пивоварний ячмінь, високобілкові зернобобові культури, раціоналізація структури агроекспорту тощо.

Характерною рисою відтворювального механізму селективного державного регулювання $\epsilon$ його висока бюджетна ефективність, тобто значний приріст податкових надходжень і можливість отримання прибутку держави (різниця між коштами, вкладеними i вилученими в результаті впровадження регуляторного заходу), що має важливе значення в умовах обмежених бюджетних коштів. Для успішного виконання завдання оптимізації доданої вартості товарів у секторах суміжних ринків та максимізації загальної доданої вартості і податкових надходжень (6-7) доцільною є оцінка бюджетної ефективності впровадження селективних регуляторних заходів на попередньому етапі та вибору найефективнішого із неоднорідної сукупності альтернативних варіантів.

Селективне регулювання відтворювальних процесів II типу (див. рис. 1) здійснюе глибинний формуючий вплив на системи суміжних ринків ЗПП, орієнтований в перспективі на зміну пропорцій відтворення та перехід системи до нової якості, забезпечення іiі сталого відтворювального розвитку. Селективне регулювання I типу здійснює стабілізуючий вплив на систему, мінімізуючи структурні та фінансові деформації ВП, відновлюючи безперервність відтворювального циклу. Загалом чим вищою є ступінь структурної та кількісно-якісної розбалансованості товарно-фінансових потоків у системах суміжних ринків, тим більшим є потенціал державного селективного регулювання.

Запропонована концепція селективного регулювання відтворювальних процесів базується на окремих аспектах теорій відтворення ресурсів та економічної стійкості, сучасній парадигмі продовольчої безпеки, інституціональній та інтеграційній концепціях, а також концепції змішаного регулювання економіки. У тій чи іншій мірі вони постають релевантними концепціями нашого дослідження, оскільки висвітлюють різні сторони селективного регулювання відтворювальних процесів у системі суміжних ринків ЗПП і дозволяють сформувати авторську цілісну концепцію. Базуючись на результатах концептуальних дослідників попередників, вона висвітлює новітній підхід до державного регулювання ВП крізь призму селективності та пріоритетності національних економічних інтересів.

Узагальнюючи результати проведених досліджень концептуальних елементів державного регулювання відтворювальних процесів інтегрованих ринків зерна та продуктів його переробки [15, с.79], напрямів та механізмів селективного регулювання «то- 
чок спаду» $\mathrm{i}$ «точок зростання» у системі суміжних ринків ЗПП (див. рис. 1), етапність та структуру методологічного підходу до регулювання ВП даних ринків можна представити у вигляді рис. 4.

Концептуальний базис методології селективного державного регулювання відтворювальних процесів у системі суміжних ринків ЗПП включає головну мету і завдання у двоєдності їх економічної та соціальної складових, чотири групи актуалізованих принципів регулювання, виділених та обгрунтованих автором, а саме: (1) суб'єктів регулювання; (2) суб'єктів ринку; (3) взаємодії суб'єктів регулювання та ринків; (4) впливу суб'єкта регулювання на відтворювальні процеси. Концепція селективного регулювання передбачає цілеспрямований вплив на деформації ВП з метою їх зменшення, на «точки зростання» у системі суміжних ринків шляхом стимулювання продукування доданої вартості товарів у виробничих секторах ринків ЗПП (див. рис. 1).

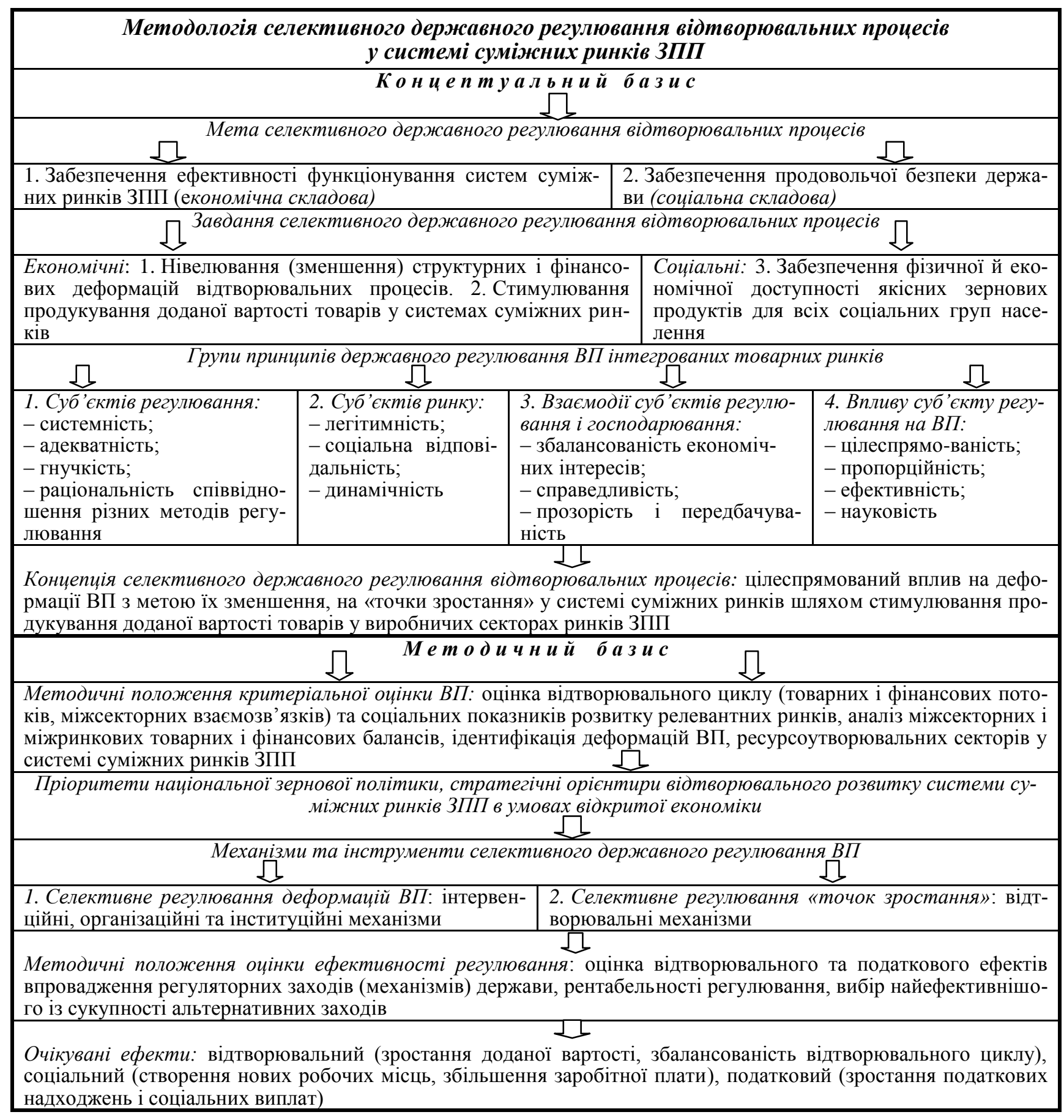

Рис. 4. Структурно-логічна схема методологічного підходу до селективного регулювання відтворювальних процесів у системі суміжних ринків зерна та продуктів його переробки [авторська розробка] 
Для ідентифікації структурних і фінансових деформацій ВП («точок спаду») та ресурсоутворювальних секторів («точок зростання») у системі суміжних ринків ЗПП передбачено використання методичних положень критеріальної оцінки відтворювальних процесів, які орієнтовані на оцінку відтворювального циклу релевантних ринків (товарних і фінансових потоків, міжсекторних взаємозв'язків і взаємодій), соціальних показників їх розвитку та управлінської ефективності суб'єктів регулювання [15, с. 102-128].

Пропоновані заходи та інструменти селективного державного регулювання ВП об'єднані в механізми, розділені за напрямами селективного впливу: (1) регулювання деформацій ВП запропоновано здійснювати 3 використанням інтервенційних, організаційних та інституційних механізмів; (2) регулювання «точок зростання» - за допомогою відтворювального та стимулюючого механізмів. Для оцінки бюджетної ефективності впровадження регуляторних заходів (механізмів) та вибору найефективніших із сукупності альтернативних заходів автором розроблено методичні положення оцінки ефективності регулювання, що передбачають розрахунок низку прикладних критеріїв (відтворювального, соціального та податкового ефектів, рентабельності регулювання), сконструйованих на базі показника із високим рівнем регуляторної еластичності - доданої вартості товару $[15$, с. 129 135].

Висновки та перспективи подальших досліджень. У ході дослідження автором обгрунтовано концепцію селективного регулювання відтворювальних процесів у системі суміжних ринків ЗПП, що синтезує два напрями (селективне регулювання деформацій ВП і «точок зростання»), які відрізняються характером впливу (стабілізуючий і формуючий) та механізмами регулювання (інтервенційні, організаційні та інституційні механізми для першого та відтворювальні механізми для другого напряму). Головна ідея авторської концепції полягає в тому, що впровадження механізмів селективного регулювання дозволить забезпечити стійкий відтворювальний розвиток системи суміжних ринків ЗПП, під яким розуміється процес кількісно-якісних змін у відтворювальному циклі, що охоплює систему суміжних товарних ринків, процес ускладнення іiї структури і розширення складу, в результаті чого підвищується ефективність функціонування системи та ії здатність зберігати рівноважний стан в умовах постійного впливу зовнішніх і внутрішніх чинників. Збереження рівноважного стану передбачає оптимізацію інтенсивності внутрішніх і зовнішніх товаропотоків у системі суміжних ринків ЗПП, що знайшло відображення у цільових об'єктних моделях селективного регулювання для сировинних $\mathrm{i}$ виробничих ринків системи.

Відмінними рисами авторської концепції селективного державного регулювання ВП у системі суміжних ринків ЗПП є цілеспрямованість впливу на «точки спаду» або «точки зростання»; системність і взаємопов'язаність регуляторних заходів, що забезпечує вирішення не одиничних, а комплексних проблем, каталізуючи позитивний системний ефект; фокусування уваги на активізації відтворювальної функції виробничих секторів інтегрованих ринків ЗПП, які генерують найбільшу частку податків у системі суміжних ринків; забезпечення ефективного використання усіх складових ринкового потенціалу.

Впровадження механізмів селективного регулювання генерує триєдність очікуваних ефектів: (1) відтворювальний - зростання доданої вартості у системі суміжних ринків, збалансованість відтворювального циклу); (2) соціальний - створення нових робочих місць, передусім у виробничих секторах інтегрованих ринків, збільшення заробітної плати; (3) податковий - зростання податкових надходжень i соціальних виплат від ринкових суб'єктів.

Прикладне значення авторських розробок визначається можливістю їх використання суб'єктами регулювання в ході обгрунтування нових та модернізації діючих регуляторних механізмів і прикладних заходів селективного впливу держави на відтворювальні процеси у системі вертикально суміжних ринків ЗПП. Перспективи подальших досліджень полягають у розробці концептуального підходу до селективного регулювання ВП на стратегічних агропродовольчих ринках України із використанням наукового підходу, висвітленого в даній статті.

\section{Література}

1. Журавлева Г.П. Экономика: учебник / Г. П. Журавлева. - М.: Юрист, 2001. - 574 с.

2. Алтухов А. И. Зерно России / А. И. Алтухов, А. С. Васютин. - М.: ЭКОНДС-К, 2002. -432 с.

3. Бородіна О. М. Державна підтримка сільського господарства: концепція, механізми, ефективність /О. М. Бородіна // Економіка і прогнозування. - 2006. - № 1. - С. 109-125.

4. Кваша С. М. Методологічний базис прийняття суспільних рішень в аграрній політиці / С. М. Кваша // Економіка АПК. - 2013. - № 8. - С. 12-21.

5. Lysyuk V.M. (2014) "Organization of the commodity market: theory and practice: monograph", Saarbrucken, Deutsehland: LAP LAMBERT Academic Publishing, 224.

6. Осташко Т. О. Ринкова трансформація аграрного сектора / Т. О. Осташко. - К.: Фенікс, 2004. - 280 с.

7. Саблук П. Т. Основні напрями удосконалення державної аграрної політики в Україні / П. Т. Саблук, Ю. Я. Лузан // Економіка АПК. - 2011. - № 5. - С. 3-16.

8. Солопов В. А. Развитие регионального рынка зерна и хлебопродуктов: науч. издание / В. А. Солопов. - Мичуринск-наукоград РФ: Изд-во Мичурин. гос. аграр. ун-та, 2006. - 315 с. 
9. Хорунжий М. Й. Завдання національної аграрної політики на сучасному етапі / М. Й. Хорунжий // Економіка АПК. - 2014. - № 2. - С. 22-29.

10. Baake P., Kamecke U., Normann H. T. (2002) "Vertical Integration and Market Foreclosure with Convex Downstream Costs”, Journal of Economics, Vol.75, № 2, 125-135.

11. Rey P, Tirole J. (2007) "Primer on Foreclosure", Handbook of Industrial Organization, Volume 3, Edited by M. Armstrong and R. Porter, Elsevier B. V., 2215.

12. Шандова Н. В. Методологія та практика управління стійким розвитком промислових підприємств: [монографія] / Н. В. Шандова. - Херсон: ПП Вишемирський В.С., 2014. - 424 с.

13. Экономический глоссарий. Сайт национальной экономической энциклопедии. [Электронный ресурс] - Режим доступа: http://vocable.ru/dictionary/ - 02.03.2016.

14. Нікішина О. В. Механізми регулювання інтегрованого зернового ринку / О. В. Нікішина. - Одеса: ІПРЕЕД НАН України, 2014. - 450 с.

15. Nikishina O. V. (2014) "Sectoral Analysis of Reproduction Processes at the Integrated Grain Market of Ukraine", Nauka i Studia, 1 (111), 105 - 111.

16. Nikishina O. V. (2014) "Criterion of Value Added in Assessing Efficiency of Integrated Markets Grain and Products his Processing in Ukraine”, Nauka i Studia, 20 (130), 52 - 57.

17. Шиян Д.В. Формування сучасної парадигми досліджень в аграрній економіці / Д. В. Шиян // Економіка АПК. - 2012. - №1. - С. 7-12.

\author{
Никишина О.В. \\ кандидат экономических наук, старший научный сотрудник \\ отдел рыночных механизмов и структур \\ Институт проблем рынка и экономико-экологических исследований НАН Украины \\ Французский бульвар, 29, г. Одесса, Украина, 65044 \\ E-mail: ksenkych@gmail.com
}

\title{
КОНЦЕПТУАЛЬНЫЙ ПОДХОД К СЕЛЕКТИВНОМУ РЕГУЛИРОВАНИЮ ВОСПРОИЗВОДСТВЕННЫХ ПРОЦЕССОВ В СИСТЕМЕ СМЕЖНЫХ РЫНКОВ ЗЕРНА И ПРОДУКТОВ ЕГО ПЕРЕРАБОТКИ
}

Предложено авторское определение категории «устойчивое воспроизводственное развитие», а именно: процесс количественно-качественных изменений в воспроизводственном цикле, который охватывает систему смежных товарных рынков, процесс усложнения ее структуры и расширения состава, в результате чего повышается эффективность функционирования системы и ее способность сохранять равновесное состояние в условиях постоянного влияния внешних и внутренних факторов.

Обоснован концептуальный подход к селективному регулированию воспроизводственных процессов в системе вертикально смежных рынков зерна и продуктов его переработки, который объединил два направления. Первое направление ориентировано на уменьшение структурных и финансовых дефрормаций воспроизводственных процессов с целью обеспечения непрерывности воспроизводственного цикла и сбалансирования товарно-финансовых потоков в системе смежных рынков зерна и зернопродуктов. Селективное регулирование деформаций или воспроизводственных «разрывов» осуществляет стабилизирующее влияние на систему и предусматривает внедрение интервенционных, организационных и институциональных механизмов.

Второе направление селективного регулирования ориентировано на стимулирование производства добавленной стоимости в ресурсообразующих секторах интегрированных рынков, которые позиционируются как «точки роста». По результатам эмпирических исследований к «точкам роста» в системе смежных рынков автором отнесены базовый аграрный сектор зернового рынка, производственный и потребительский сектора рынков продуктов зернопереработки. Селективное регулирование «точек роста» осуществляет глубокое формирующее влияние на систему смежных рынков путем реализации воспроизводственных механизмов, которые генерируют налоговый, социальный и воспроизводственный эффекты. Активизация «точек роста», то есть стимулирование производства добавленной стоимости в ресурсогенерирующих секторах, формирует задание оптимизации внутренних и внешних товарных по- 
токов в системе смежных рынков зерна и продуктов, что нашло отражение в целевых объектных моделях селективного регулирования для сырьевых и производственных рынков системы.

Главная идея авторской концепции состоит в том, что внедрение механизмов селективного регулирования позволит обеспечить устойчивое воспроизводственное развитие системы смежных рынков зерна и продуктов его переработки. Предложенный концептуальный подход формирует теоретический базис методологии селективного регулирования воспроизводственных процессов в системе смежных рынков.

Ключевые слова: рынки зерна и продуктов его переработки, система смежных рынков, деформации воспроизводственных процессов, ресурсообразующие сектора, оптимизация товарных потоков, селективное регулирование.

\author{
Nikishina 0. \\ Ph.D. in Economics, Senior Researcher \\ Department of market mechanisms and structures \\ Institute of market problems and economic \& ecological research \\ of National Academy of Sciences of Ukraine \\ Frantsuzskiy boulevard, 29, Odessa, Ukraine, 65044 \\ E-mail: ksenkych@gmail.com
}

\title{
CONCEPTUAL APPROACH TO SELECTIVE REGULATION OF REPRODUCTION PROCESSES IN SYSTEM OF ADJACENT GRAIN MARKETS AND ITS PRODUCTS PROCESSING
}

Proposed author's definition of category «sustainable reproduction development», namely: the process of quantitative and qualitative changes in reproduction cycle, which covers system of adjacent commodity markets, the process complexity of its structure and expansion of composition, resulting in increased efficiency of system and its ability to keep equilibrium state under constant influence of external and internal factors.

Substantiated conceptual approach to the selective regulation of reproduction processes in system of vertically adjacent markets grain and its products processing, which combined two directions. First direction is oriented on the decrease structural and financial deformations of reproduction processes in order to ensure the continuity of the reproduction cycle and the balance of commodity and financial flows in the system of adjacent markets grain and grain products. Selective regulation of deformations or the reproduction «gaps» provides a stabilizing influence on system and envisages the introduction of intervention, organizational and institutional mechanisms.

Second direction of selective regulation is oriented at stimulating the production of value added in the resource-forming sectors of integrated markets, which are positioned as "growth points». By results of empirical research to the "growth points» in system adjacent markets author attributed the basic agrarian sector of grain market, the production and consumer sectors of markets grain products. Selective regulation of «points of growth» provides profound formative influence on system of adjacent markets by implementing of reproduction mechanisms that generate tax, social and reproductive effects. Activating "growth points», that is the stimulate the production of added value in resource-generating sectors, forms the task of optimization internal and external commodity flows in system adjacent markets of grain and products grain, which is reflected in targeted object models for selective regulation of raw materials and production markets the system.

Main idea the author's conception consists in the fact that implementation the mechanisms of selective regulation will ensure sustainable reproduction development of system adjacent markets of grain and its products processing. Proposed conceptual approach forms the theoretical basis of the methodology of selective regulation of reproduction processes in system adjacent markets.

Keywords: markets of grain and its products processing, system adjacent markets, deformations of reproduction processes, resources-forming sectors, optimization commodity flows, selective regulation.

\section{References}

1. Zhuravleva., H. P. (2001). Эkonomyka: Uchebnyk. M.: Yuryst.

2. Altukhov,, A. Y., \& Vasiutyn, A. S. (2002). Zerno Rossyy. M.: ЭKONDS-K. 
3. Borodina, O. M. (2006). Derzhavna pidtrymka silskoho hospodarstva: Kontseptsiia, mekhanizmy, efektyvnist. Ekonomika I Prohnozuvannia, 1, 109-125.

4. Kvasha, S. M. (2013). Metodolohichnyi bazys pryiniattia suspilnykh rishen v ahrarnii politytsi. Ekonomika APK, 8, 12-21.

5. Lysyuk, V. M. (2014). Organization of the commodity market: Theory and practice. Saarbrucken,Deutsehland: LAP LAMBERT Academic Publishing.

6. Ostashko, T. O. (2004). Rynkova transformatsiia ahrarnoho sektora. K.: Feniks.

7. Sabluk, P. T., \& Luzan, I. I. (2011). Osnovni napriamy udoskonalennia derzhavnoi ahrarnoi polityky v Ukraini. Ekonomika APK, 5, 3-16.

8. Solopov, V. A. (2006.). Razvytye rehyonalnoho ronka zerna y khleboproduktov. RF: Mychuryn.

9. Khorunzhyi, M. I. (2014). Zavdannia natsionalnoi ahrarnoi polityky na suchasnomu etapi. Ekonomika APK, 2, 22-29.

10. Baake, P., Kamecke, U., \& Normann, H. T. (2002). Vertical Integration and Market Foreclosure with Convex Downstream Costs. Journal of Economics, 75(2), 125-135.

11. Rey, P., \& Tirole, J. (2007). , "Primer on Foreclosure”, Handbook of Industrial Organization, Volume (Vol. 3).

12. Shandova, N. V. (2014). Metodolohiia ta praktyka upravlinnia stiikym rozvytkom promyslovykh pidpryiemstv. Herson: PP Vyshemyrskyi V.S.

13. Эkonomycheskyi hlossaryi. Sait natsyonalnoi эkonomycheskoi эntsyklopedyy. Retrieved March 02, 2016, from http://vocable.ru/dictionary Ukrainy.

14. Nikishyna, O. V. (2014). Mekhanizmy rehuliuvannia intehrovanoho zernovoho rynku. Odesa:: IPREED NAN

15. Nikishina, O. V. (2014). "Sectoral Analysis of Reproduction Processes at the Integrated Grain Market of Ukraine". Nauka I Studia, 1(111), 105-111.

16. Nikishina, O. V. (2014). Criterion of Value Added in Assessing Efficiency of Integrated Markets Grain and Products his Processing in Ukraine. 20(130), 52-57.

17. hyian, D. V. (2012). Formuvannia suchasnoi paradyhmy doslidzhen v ahrarnii ekonomitsi. Ekonomika APK, $1,7-12$.

Received 10 March 2016

Approved 24 March 2016

Available in Internet 29.06.2016 